\title{
Residual effect of a few herbicides on chlorophyll content and primary productivity of succeeding crops and associated weeds
}

\author{
A. N. RAO* \\ School of Studies in Botany, Vikram University, Ujjain 456010 (M. P.), India \\ (Received: January 9, 1980)
}

\begin{abstract}
The residual effect of a few herbicides viz: Atrataf (atrazine), 2,4-D and Aresin (monolinuron) sprayed in the previous season on the pigment concentration and primary productivity of the crops (viz: Zea mays and Cajanus cajan) grown in rotation, as well as their associated weeds has been studied. The results indicate that the residues of all the three herbicides were non toxic to Zea mays and toxic to Cajanus cajan as an increase in chlorophyll content and primary productivity occurred in the former, whereas the contrary is true for the latter. Weeds from residual plots have shown a considerable decrease in the chlorophyll content and primary productivity. The most susceptible weed to all the three herbicides was Acalypha malabarica, while Echinochloa colonum is susceptible to the residues of Atrazine but is tolerant to the residues of the other two herbicides. Recommendations based on the observations are presented in the paper.
\end{abstract}

\section{INTRODUCTION}

The eventual fate of pesticides is decomposition, but the variable rates of these breakdown reactions lead to the occurrence of some soil residues. When young peach or apple trees are planted in old apple orchards, where arsenic residues were present, those residues sometimes caused severe injury or death (V a n$\mathrm{d}$ e c a v e y e et al., 1936; B 1 o d g e t, 1941). Similar results of phytotoxicity were reported later for different herbicides like monuron ( $\mathrm{S} \mathrm{h}$ a d b o l d et al., 1964) diuron and monuron (A r l e et al., 1965) atrazine to sugarbeets (F r a n k, 1965) and amitrol ( D u b e y and R a o, 1975). Thus carry over of the pesticides in the soil becomes a problem with double cropping systems

*Present address: A. N. Rao, Research Officer Centre for Photosynthesis, School of Life Sciences University of Hyderabad, Hyderabad 500134 India. 
(during one growing season or where crop rotation is practised). In order to evaluate the phytotoxic residual persistent potentialities of the herbicides and to assess the possible injury due to these residues to the crops grown in rotation with the sprayed crops, a few experiments have been conducted. In the present investigation chlorophyll was used as indicator of residual toxicity ( $\mathrm{D}$ u b e y and $\mathrm{R}$ a o, 1975; P u r o h i t et al., 1976; $\mathrm{R}$ a o et al., 1978) and in addition the impact of these residues on the net primary production (NPP) and gross primary production (GPP) was also studied, in order to assess the losses caused by these residues in crops and to study the impact of these residues on the efficiency of the weeds.

\section{MATERIAL AND METHODS}

Three herbicides belonging to three different groups were selected for study:

Atrataf: (2-chloro-4-ethylamino-6-isopropylamino-1-3-5-5-triazine) of the triazine group (atrazine);

2,4-D: (2,4-dichlorophenoxyacetic acid) of the phenoxys group;

Aresin: (3(4-chlorophenyl)-1-methoxy-1-methyl)urea) of the substituted urea group (monolinuron).

The crops selected for study were pigeonpea (Cajanus cajan cv. 'Pusa Agethi') and maize (Zea mays cv. 'J. 603'). The experiments were conducted at the Govt. seed multiplication farm of Ujjain during 1975-1976. The experimental plots were of $7 \times 7 \mathrm{~m}$ size each. Each herbicide was applied in 3 doses $1 \mathrm{~kg} / \mathrm{ha}, 3 \mathrm{~kg} / \mathrm{ha}$, $5 \mathrm{~kg} / \mathrm{ha}$. Each dose in three replicates. The herbicides were sprayed as preemergence treatment during the Rabi season (Post monsoon season i. e. on 20th of November 1975) in sorghum fields. Sorghum crops are harvested in the Rabi season also ( $\mathrm{J} \circ \mathrm{h} \mathrm{n}$ and $\mathrm{L}$ i $\mathrm{k}$ y $\mathrm{n}$ a $\mathrm{t} \mathrm{h}$ a $\mathrm{n}$, 1967).

In order to test the residual toxicity of the sprayed herbicides on the crops grown in rotation, the same plots were sown with Cajanus cajan and Zea mays in the Kharif season (i.e. Rainy season). When the plants were one month old, the leaves of plants and associated weeds were brought to the laboratory and the chlorophyll content was estimated by the methods of A r n o n (1949) and $\mathrm{D}$ e $\mathrm{x} \mathrm{bu} \mathrm{r} \mathrm{y}$ and $\mathrm{Ye} \mathrm{n} \mathrm{a} \mathrm{ch}$ (1956). The reduction in chlorophyll content in comparison to that of controls was taken as an indicator of residual toxicity as it has been proved that reduction in chlorophyll because of residues indicates the pollution potentials of the herbicides and the chlorophyll content can be taken as an index ( $\mathrm{P}$ u $\mathrm{r}$ o h i t et al., 1976; $\mathrm{R}$ a o et al., 1978). From the same plots leaf samples of uniform size of both crop and weeds were picked early in the morning and brought to the laboratory in moistened polythene bags so as to preserve the full turgidity of the leaves. These leaf samples were used for estimation of primary productivity, i.e. gross primary productivity and net primary productivity by the leaf disc method (S e t 1 i k et al., 1960; M i s r a et al., 1968; A v r a t o v- 
s c u k ova, 1968; S e t li k and S e s t a k, 1971; B handari Se n, 1973). The results presented in the paper are means of 5 replicates for each treatment.

\section{RESULTS}

The impact of the residues of all three herbicides on the chlorophyll content of the two crops tested and of the associated nine weeds is presented in Table 1. The that herbicides were non toxic to maize and toxic to pigeonpea as an increase in chlorophyll occurred in the first case and as the opposite is true in the other. Among the three herbicides, Atrataf has a high residual toxicity for pigeonpea, these residues caused a reduction of $3.1 \%, 24.4 \%, 36.4 \%$ of the chlorophyll in comparison to the control on plots with doses 1,3 and $5 \mathrm{~kg} / \mathrm{ha}$, respectively. Next comes Aresin, whose residues caused a $1.6 \%, 12.4 \%$ and $22.5 \%$ reduction of chlorophyll in comparison with the control. While 2,4-D is much less toxic than the two other pesticides in 1 and $3 \mathrm{~kg} / \mathrm{ha}$ rates, but in $5 \mathrm{~kg} / \mathrm{ha}$ rate it also caused a reduction of $20.7 \%$ of chlorophyll. With all three rates of the herbicides, the residues were non toxic to maize, and Atrataf, 2,4-D and Aresin caused an increase in chlorophyll content by $17.1,12.1$ and $12.1 \%$, respectively in the $5 \mathrm{~kg} / \mathrm{ha}$ rate. Even in other doses (i.e. 1 and $3 \mathrm{~kg} / \mathrm{ha}$ ) there is an increase in the chlorophyll content.

Weeds from residual plots showed a considerable decrease in the chlorophyll content, and the most susceptible weed to all the three herbicidal residues was Acalypha malabarica which showed $47.18 \%, 25.5$ and $38.54 \%$ decrease on the plots with $5 \mathrm{~kg} / \mathrm{ha}$ rate of Atrataf, 2,4-D and Aresin respectively in addition to its susceptibility even to residues of $1 \mathrm{~kg} / \mathrm{ha}$. Alysicarous spp. is highly susceptible to Atrataf residues with $5 \mathrm{~kg} / \mathrm{ha}$ rate, where $40.1 \%$ reduction was observed in comparison to the control. The residues of $5 \mathrm{~kg} / \mathrm{ha}$ rate of all the three herbicides are highly toxic to weeds in comparison to other rates. The most resistant weed to the herbicidal residues, is Cyperus rotundus which shows only $13.4 \%$ reduction at $5 \mathrm{~kg} / \mathrm{ha}$ rate of atrazine residues, and even less i.e. $4.4 \%$ and $5.9 \%$ with 1 and $3 \mathrm{~kg} / \mathrm{ha}$ doses. Echinochloa colonum was susceptible to the residues of atrazine, but tolerent to those of the other two herbicides. The next tolerent weed is $X$ anthium strumarium which does not show a reduction in chlorophyll content by more than $19.5 \%$ with any dose of any herbicide. Other results of chlorophyll content are presented in Table 1.

The results of impact of the residues of Atrataf on the gross primary productivity (GPP) and net primary productivity (NPP) are presented in Table 2. The results are in support of the chlorophyll content in that no reduction in GPP and NPP was observed in maize, while the reduction was observed in pigeonpea. The results of GPP and NPP confirm that Atrataf has a high residual toxicity. In susceptible pigeonpea the herbicide residues of $5 \mathrm{~kg} /$ ha plots caused a $23.1 \%$ 
Ta b le 1

Total chlorophyll content (mg/g fresh weight) of cheps and weeds as influenced by the phytotoxic residues of herbicides sprayed in the previous season

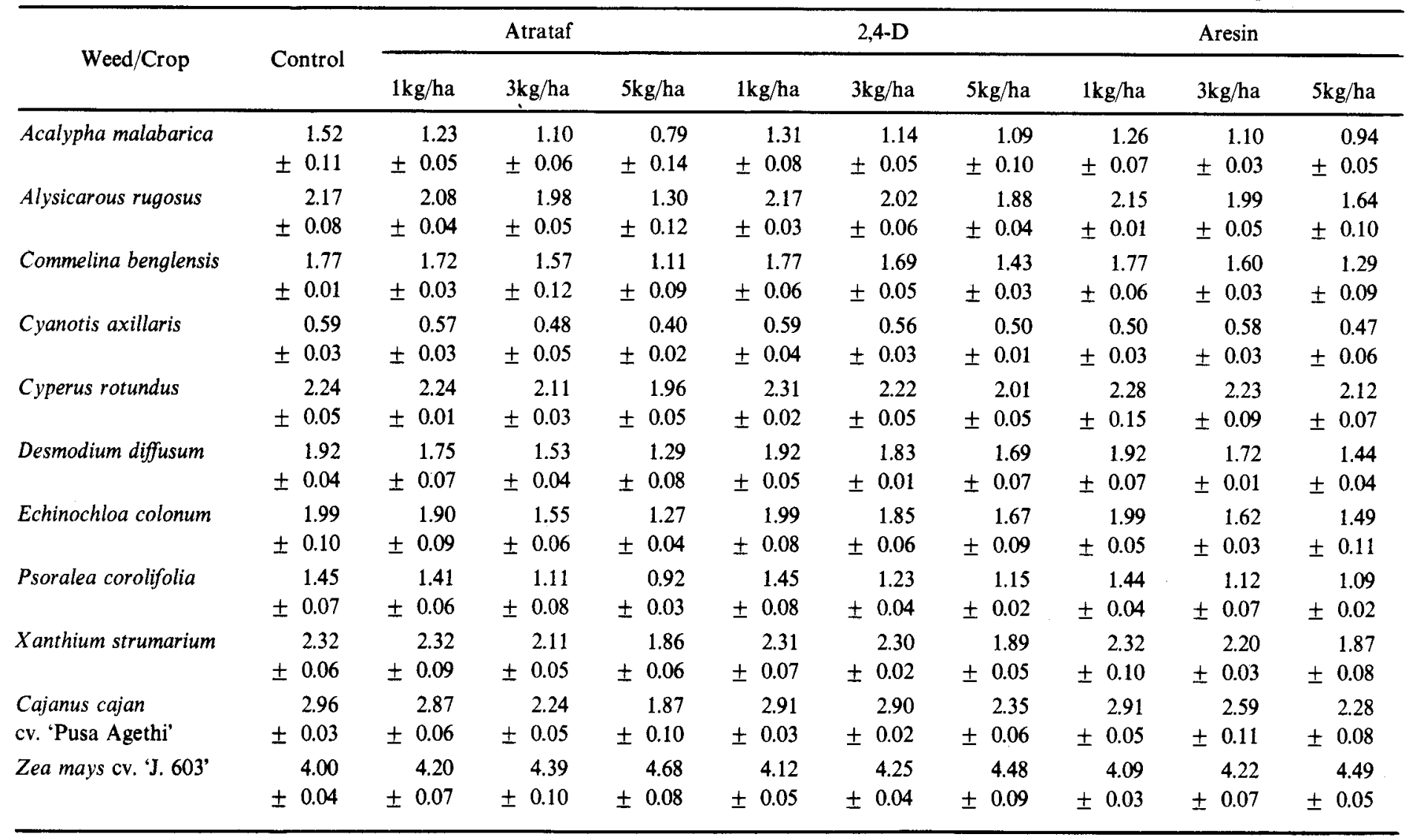

\footnotetext{
\pm - standard deviation.
} 
T a b l e 2

Showing influence of Atrataf residues on gross primary production (GPP)* net primary production (NPP)*, and respiration (RESPN)* of crops and weeds in next season

\begin{tabular}{|c|c|c|c|c|c|c|c|c|c|c|c|c|}
\hline \multirow{2}{*}{ Weed/Crop } & \multicolumn{4}{|c|}{ RESPN } & \multicolumn{4}{|c|}{ NPP } & \multicolumn{4}{|c|}{ GPP } \\
\hline & Control & $1 \mathrm{~kg} / \mathrm{ha}$ & $3 \mathrm{~kg} / \mathrm{ha}$ & $5 \mathrm{~kg} / \mathrm{ha}$ & Control & $1 \mathrm{~kg} / \mathrm{ha}$ & $3 \mathrm{~kg} / \mathrm{ha}$ & $5 \mathrm{~kg} / \mathrm{ha}$ & Control & $1 \mathrm{~kg} / \mathrm{ha}$ & $3 \mathrm{~kg} / \mathrm{ha}$ & $5 \mathrm{~kg} / \mathrm{ha}$ \\
\hline \multicolumn{13}{|l|}{ Acalypha } \\
\hline malabarica & 16.0 & 15.8 & 15.4 & 13.7 & 22.0 & 19.2 & 15.2 & 12.1 & 38.0 & 35.0 & 30.6 & 25.8 \\
\hline \multicolumn{13}{|l|}{ Alysicarous } \\
\hline rugosus & 15.6 & 15.3 & 14.6 & 12.5 & 36.8 & 34.5 & 31.5 & 21.3 & 52.4 & 49.8 & 46.1 & 33.8 \\
\hline \multicolumn{13}{|l|}{ Commelina } \\
\hline bengalensis & 41.3 & 40.8 & 37.9 & 36.3 & 38.4 & 36.9 & 32.1 & 26.6 & 79.7 & 77.7 & 70.0 & 62.9 \\
\hline \multicolumn{13}{|l|}{ Cyanotis } \\
\hline axillaris & 43.9 & 42.9 & 41.7 & 40.0 & 22.6 & 20.2 & 19.3 & 16.7 & 66.5 & 63.1 & 60.9 & 56.8 \\
\hline \multicolumn{13}{|l|}{ Cyperus } \\
\hline rotundus & 12.6 & 12.3 & 11.3 & 9.8 & 84.3 & 81.2 & 80.5 & 77.5 & 96.9 & 93.5 & 91.8 & 87.3 \\
\hline \multicolumn{13}{|l|}{ Desmodium } \\
\hline diffusum & 17.9 & 17.2 & 15.2 & 12.8 & 96.5 & 94.1 & 87.5 & 78.4 & 114.4 & 111.3 & 103.7 & 91.2 \\
\hline \multicolumn{13}{|l|}{ Echinochloa } \\
\hline colonum & 53.1 & 52.1 & 50.3 & 42.5 & 58.1 & 54.1 & 51.3 & 39.2 & 111.2 & 106.2 & 101.6 & 81.7 \\
\hline \multicolumn{13}{|l|}{ Psoralea } \\
\hline corolifolia & 13.0 & 12.7 & 11.4 & 10.5 & 63.3 & 61.7 & 57.8 & 48.5 & 76.3 & 74.4 & 69.2 & 59.0 \\
\hline \multicolumn{13}{|l|}{ Xanthium } \\
\hline strumarium & 14.7 & 14.1 & 13.2 & 11.7 & 85.1 & 81.3 & 78.4 & 59.7 & 99.8 & 95.4 & 91.6 & 70.4 \\
\hline \multicolumn{13}{|l|}{ Cajanus cajan } \\
\hline cv. 'Pusa Agethi' & 52.6 & 51.4 & 40.8 & 40.4 & 231.0 & 212.2 & 171.3 & 146.3 & 283.6 & 263.6 & 212.1 & 186.7 \\
\hline Zea mays cv. 'J. 603' & 137.6 & 148.1 & 150.3 & 151.8 & 445.0 & 481.2 & $492: 7$ & 546.5 & 582.6 & 629.3 & 643.0 & 698.3 \\
\hline
\end{tabular}

$m \mathrm{mg} / \mathrm{m}^{2} / \mathrm{h}^{1}$ 
T a b l e 3

Showing the influence of Aresin residues on gross primary productivity (GPP)*, net primary productivity (NPP)* and respiration (RESPN)* of crops and weeds in next season

\begin{tabular}{|c|c|c|c|c|c|c|c|c|c|c|c|c|}
\hline \multirow{2}{*}{ Weeds/Crop } & \multicolumn{4}{|c|}{ RESPN } & \multicolumn{4}{|c|}{ NPP } & \multicolumn{4}{|c|}{ GPP } \\
\hline & Control & $1 \mathrm{~kg} / \mathrm{ha}$ & $3 \mathrm{~kg} / \mathrm{ha}$ & $5 \mathrm{~kg} / \mathrm{ha}$ & Control & $1 \mathrm{~kg} / \mathrm{ha}$ & $3 \mathrm{~kg} / \mathrm{ha}$ & $5 \mathrm{~kg} / \mathrm{ha}$ & Control & $1 \mathrm{~kg} / \mathrm{ha}$ & $3 \mathrm{~kg} / \mathrm{ha}$ & $5 \mathrm{~kg} / \mathrm{ha}$ \\
\hline \multicolumn{13}{|l|}{ Acalypha } \\
\hline malabarica & 16.0 & 16.1 & 15.7 & 15.1 & 22.0 & 19.8 & 17.9 & 12.5 & 38.0 & 35.9 & 33.6 & 27.6 \\
\hline \multicolumn{13}{|l|}{ Alysicarous } \\
\hline rugosus & 15.6 & 15.5 & 15.1 & 12.9 & 36.8 & 35.2 & 32.6 & 23.4 & 52.4 & 50.7 & 47.7 & 36.3 \\
\hline \multicolumn{13}{|l|}{ Commelina } \\
\hline bengalensis & 41.3 & 41.1 & 38.7 & 37.8 & 38.4 & 38.2 & 34.2 & 28.0 & 79.7 & 79.3 & 72.9 & 65.8 \\
\hline \multicolumn{13}{|l|}{ Cyanotis } \\
\hline axillaris & 43.9 & 42.1 & 41.4 & 40.3 & 22.6 & 18.3 & 16.7 & 15.2 & 66.5 & 60.4 & 58.1 & 55.8 \\
\hline \multicolumn{13}{|l|}{ Cyperus } \\
\hline rotundus & 12.6 & 12.5 & 12.2 & 10.2 & 84.3 & 82.1 & 80.4 & 79.1 & 96.9 & 94.6 & 92.6 & 89.3 \\
\hline Desmodium & & & & & & & & & & & & \\
\hline deffusum & 17.9 & 17.6 & 15.4 & 12.9 & 96.5 & 95.2 & 89.2 & 79.6 & 114.4 & 112.8 & 104.6 & 92.5 \\
\hline \multicolumn{13}{|l|}{ Echinochloa } \\
\hline colonum & 53.2 & 52.9 & 51.8 & 43.6 & 58.1 & 57.3 & 53.4 & 41.4 & 111.2 & 110.2 & 105.2 & 85.0 \\
\hline \multicolumn{13}{|l|}{ Psoralea } \\
\hline corolifolia & 13.0 & 12.8 & 12.1 & 11.2 & 63.3 & 62.2 & 59.1 & 42.1 & 76.3 & 75.0 & 71.2 & 53.3 \\
\hline \multicolumn{13}{|l|}{ Xanthium } \\
\hline strumarium & 14.7 & 14.5 & 13.9 & 11.5 & 85.1 & 83.1 & 81.5 & 61.5 & 99.8 & 97.6 & 95.4 & 73.2 \\
\hline \multicolumn{13}{|l|}{ Cajanus cajan } \\
\hline \multicolumn{13}{|l|}{ cv. 'Pusa } \\
\hline Agethi' & 52.6 & 51.8 & 51.1 & 41.8 & 231.0 & 229.2 & 218.6 & 172.9 & 283.6 & 281.0 & 229.7 & 214.7 \\
\hline \multicolumn{13}{|l|}{ Zea mays } \\
\hline cv. 'J.603' & 137.6 & 147.9 & 149.3 & 150.4 & 445.0 & 479.2 & 488.1 & 510.4 & 582.6 & 627.1 & 637.4 & 660.8 \\
\hline
\end{tabular}

$* \mathrm{mg} / \mathrm{m}^{2} / \mathrm{h}$. 
Ta b l e 4

Showing the influence of 2,4-D residues on gross primary productivity (GPP)*, net primary productivity (NPP)*, and respiration (RESPN)* of crops and . weeds in next season

\begin{tabular}{|c|c|c|c|c|c|c|c|c|c|c|c|c|}
\hline \multirow{2}{*}{ Weed/Crop } & \multicolumn{4}{|c|}{ RESPN } & \multicolumn{4}{|c|}{ NPP } & \multicolumn{4}{|c|}{ GPP } \\
\hline & Control & $1 \mathrm{~kg} / \mathrm{ha}$ & $3 \mathrm{~kg} / \mathrm{ha}$ & $5 \mathrm{~kg} / \mathrm{ha}$ & Control & $1 \mathrm{~kg} / \mathrm{ha}$ & $3 \mathrm{~kg} / \mathrm{ha}$ & $5 \mathrm{~kg} / \mathrm{ha}$ & Control & $1 \mathrm{~kg} / \mathrm{ha}$ & $3 \mathrm{~kg} / \mathrm{ha}$ & $5 \mathrm{~kg} / \mathrm{ha}$ \\
\hline \multicolumn{13}{|l|}{ Acalypha } \\
\hline malabarica & 16.0 & 15.7 & 14.7 & 13.8 & 22.0 & 19.1 & 16.7 & 15.7 & 38.0 & 34.8 & 31.1 & 29.5 \\
\hline \multicolumn{13}{|l|}{ Alysicarous } \\
\hline rugosus & 15.6 & 15.2 & 14.8 & 13.9 & 36.8 & 35.1 & 34.3 & 27.2 & 52.4 & 51.1 & 49.1 & 41.1 \\
\hline \multicolumn{13}{|l|}{ Commelina } \\
\hline bengalensis & 41.3 & 40.4 & 36.3 & 33.7 & 38.4 & 38.9 & 37.3 & 32.4 & 79.7 & 79.2 & 73.6 & 66.1 \\
\hline \multicolumn{13}{|l|}{ Cyanotis } \\
\hline axillaris & 43.9 & 41.2 & 39.2 & 38.4 & 22.6 & 18.8 & 20.1 & 17.5 & 66.5 & 60.0 & 59.3 & 55.9 \\
\hline \multicolumn{13}{|l|}{ Cyperus } \\
\hline rotundus & 12.6 & 12.1 & 11.9 & 9.4 & 84.3 & 851 & 81.2 & 82.5 & 96.9 & 97.2 & 93.1 & 91.9 \\
\hline \multicolumn{13}{|l|}{ Desmodium } \\
\hline diffusum & 17.9 & 17.9 & 15.1 & 12.2 & 96.5 & 96.9 & 90.3 & 81.3 & 114.4 & 114.8 & 105.4 & 93.5 \\
\hline Echinochloa & & & & & $\bullet$ & & & & & & & \\
\hline colonum & 53.1 & 53.1 & 50.6 & 48.4 & 58.1 & 58.5 & 55.5 & 46.3 & 111.2 & 111.6 & 106.1 & 94.7 \\
\hline Psoralea & & & & & & & & . & & & & \\
\hline corolifolia & 13.0 & 12.5 & 11.7 & 10.6 & 63.8 & 63.6 & 62.4 & 45.2 & 76.3 & 76.1 & 74.1 & 55.8 \\
\hline \multicolumn{13}{|l|}{ Xanthium } \\
\hline strumarium & 14.7 & 14.1 & 12.4 & 10.2 & 85.1 & 83.9 & 83.3 & 67.3 & 99.8 & 98.0 & 95.4 & 77.5 \\
\hline Cajanus cajan & & & & & & & & & & & & \\
\hline cv. 'Pusa & & & & & & & & & . & & & \\
\hline Agethi' & 52.6 & 51.5 & 48.3 & 39.4 & 231.0 & 230.7 & 210.3 & 180.4 & 283.6 & 282.2 & 258.6 & 219.8 \\
\hline \multicolumn{13}{|l|}{ Zea mays } \\
\hline cv.'J. 603' & 137.6 & 149.3 & 149.7 & 150.3 & 445.0 & 480.5 & 489.5 & 537.6 & 582.6 & 629.8 & 639.2 & 687.9 \\
\hline
\end{tabular}


reduction of respiration $36.6 \%$ reduction of NPP and $34.1 \%$ of GPP in comparison to that of the control. Even the $3 \mathrm{~kg} / \mathrm{ha}$ plots of Atrataf residues were equally toxic to pigeonpea causing a reduction of respiration, NPP and GPP. On all the plots an increase in GPP and NPP of the maize was observed thereby conforming with the results of chlorophyll concentration. The maximum increase of GPP and NPP were observed on $5 \mathrm{~kg} /$ ha plots.

Among the weeds Alysicarous rugosus has shown the highest percentage reduction in GPP $(36.5 \%)$, while Acalypha malabarica has $32.08 \%$ reduction in GPP in comparison to control, but as far as reduction in NPP was concerned the highest reduction (50.03\%) in comparison to control was found in Acalypha spp. and less $(42.0 \%)$ in Alysicarous spp. The results of chlorophyll concentration regarding the resistence of $C$ yperus rotundus are confirmed by small reduction of NPP and GPP - only $8.0 \%$ and $9.9 \%$ respectively, in comparison to the control.

The influence of Aresin residues on NPP and GPP of crops and weeds are given in Table 3. They show that Aresin has a lesser residual toxicity than Atrataf but higher than 2,4-D. In the lower dose, i.e. $1 \mathrm{~kg} / \mathrm{ha}$, the residues are comparatively less toxic to pigeonpea where only $1.1 \%$ reduction of GPP in comparison to control was observed, but on the plots with $3 \mathrm{~kg} / \mathrm{ha}$ there was $22.8 \%$ reduction and on $5 \mathrm{~kg} / \mathrm{ha}$ plots $29.1 \%$. Even with Aresin the most susceptible were Acalypha spp. and Alysicarous and least was Cyperus spp.

The influence of 2,4-D residues on NPP and GPP of crops and weeds is shown in Table 4. The 2,4-D residues were least toxic in comparison to others, but reduced the GPP of pigeonpea by $26.9 \%$ in comparison to control in the plants from the plots with $5 \mathrm{~kg} /$ ha dose. Even NPP was reduced by $21.9 \%$ and a greater reduction in respiration was observed in the plants from $5 \mathrm{~kg} / \mathrm{ha}$ plots which show $25.0 \%$ reduction in respiration in comparison to the control. The GPP and NPP of maize were increased by $5.7 \%$ and $7.9 \%, 6.8 \%$ and $10.0 \%, 12.3 \%$ and $25.2 \%$ respectively on the 1.3 and $5 \mathrm{~kg} /$ ha treated plots respectively. Among the weeds the susceptible plants are Acalypha spp., Xanthium spp., both of which showed $22.3 \%$ reduction in GPP, while Acalypha spp. has a higher $(27.6 \%)$ reduction in NPP than Xanthium spp. $(20.9 \%)$. It is due to the differences in reduction in respiration. Cyperus rotundus and Desmodium spp. are resistant. Other results are presented in Table 4.

\section{DISCUSSION}

The results indicate that Atrataf of the triazine group has a higher residual persistence than Aresin which belong to urea and this in turn shows a higher residual toxicity than 2,4-D which is of the phenoxy group. These results are in support of K e a r n e y et al., (1969). The results of reduction of chlorophyll 
content, in the susceptible plant pigeonpea and increase in the maize plants on the Atrataf residual plots conform with the study of $\mathrm{W}$ h e e $1 \mathrm{e} \mathrm{r}$ and $\mathrm{H}$ a $\mathrm{m}$ i 1to $n$ (1968) who found that there is loss of chlorophyll content in the susceptible plants. In the present investigation, it has been found that the residues of urea herbicides are also capable of reducing the chlorophyll content of the susceptible plants.

The inhibition of photosynthetic rates in the susceptible plants, i. e. pigeonpea and other weeds supports the idea that Atrataf residues are herbicidal via an effect on photosynthesis $(\mathrm{O} l \mathrm{e} \mathrm{c} \mathrm{h}, 1966)$ and the retardation of respiration observed is in support of F u n d e r b u r k and D a v i s (1963). O l e c h (1966) has shown that atrazine inhibits respiration. But the comparatively lesser inhibition of respiration in comparison to the control suggest that inhibition of respiration was indirect and caused by a lowered level of assimilates as a result of inhibition of photosynthesis. Both the processes might occur in nature. The observed inhibition of the photosynthetic rate in the susceptible plants with Aresin residual soil, is due to inhibition of the photosynthetic rate ( $\mathrm{M}$ o $\mathrm{r}$ l a $\mathrm{n} \mathrm{d,} \mathrm{1969).} \mathrm{The}$ tolerence of maize and susceptibility of pigeonpea to Aresin residues can be attributed to the differential accumulation and metabolism of the chemical. The higher respiration lossed of the plants from 2,4-D residual soils in support the

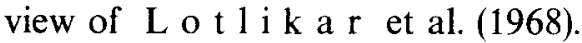

On the basis of the results some suggestions can be made regarding the usage of the three herbicides in relation to crop rotation practices, in order to prevent the crops from herbicidal pollution. As maize is tolerant to the residues of all the herbicides studied, it is worth recommending maize cultivation in areas previously treated with the herbicides. As it has been proved that these residues are also toxic to the associated weeds (with few exception) and their productivity is decreased, plantation of maize proves to be more economical as well, as the residues can control the weeds over the first month, which is the critical period of competition between crops and weeds. In the rotation system the herbicide with short residual action must be used immediately preceding a sensitive crop. It can be suggested from these studies that usage of higher dosages of the herbicides (i. e. $5 \mathrm{~kg} / \mathrm{ha}$ ) should be discontinued as there is a danger of accumulation of the herbicidal residues which may cause ecological imbalance leading to problems of pollution in the long run.

\section{Acknowledgement}

The author is highly thankful to Dr P. S. Dubey for occasional guidance and to Prof. I. P. Mall, Head of the School of Studies in Botany for providing the Laboratory facilities and for encouragement. He is also thankful to C. S. I. R. for granting a Research Fellowship and to Dr S. Subba Rao for suggestions during the tenure of the present work. 


\section{REFERENCES}

A $\mathrm{r}$ n o $n$ D. I., 1949. Copper enzymes in isolated chloroplasts poly phenoloxidase in Beta vulgaris. Plant Physiology, 24: 1-15.

A r l e H. F., M i ll e r J. H., S h e e t s T. J., 1965. Disappearence of herbicides from irrigated soils. Weeds, 13: 56.

A v r a t o v s c u k o v a ., 1968. Differences in photosynthetic rate of leaf discs in five tabocco varieties. Photosynthetica, 2: 149-160.

B 1 o d g e t t E. C., 1941. A systemic arsematic arsenic toxicity of peach and apricot on old apple land. Plant Disease Reporter, 25: 549.

B h a n d a r i S e n D. N., 1973. Productivity studies in some arid zone Cucurbitaceous spp. Trop. Ecol. 14: 155-157.

van D e c a ve y e S. C., Horne r G. M., K e a t o n C. M., 1936. Unproductiveness of certain orchards soils as related lo lead arsenate spray accumulations. Soil Sci. 42: 203.

D e x b u r y A. C., Y e n t a c h A. C., 1956. Plankton pigment monographs. J. Marine. Res. 15: $92-101$.

D u b e y P.S., R a o A. N., 1975. Amitrol toxicity to crops and its reversal by urea. Curr. Sci. 44 (7): $247-248$.

F r a n .k R., 1965. Atrazine carryover in production of sugar beets in South Western Ontario. W. Ontario Agr. School, Ridgetown, Ontario, Can. Manuscript.

F u n d e r b u r k H. H., D a v i s D. E., 1963. The metabolism of ${ }^{14} \mathrm{C}$ - chain and ring labelled simazine by corn and the effect of atrazine on plant respirarory systems. Weeds, 11: 101-104.

J o h n P. U., Li k y n a t h a n P. S., 1967. Report - cropping pattern in Madhya Pradesh. National Council of applied economic research, New Delhi.

K e a r n e y P.C., N a s h G., I s e n s e e A.R., 1969. Persistence of pesticides residues in soils: 54-67. [In:] M i l l e r M. W., B e r g G. C. (eds): Chemical fallout: Current research on persistent pesticides, Spring field. III tome.

L o t l i k a r P. D., Re m m e r t L. F., Fre e d V. H., 1968. Effect of 2,4-D and other herbicides on oxidative phosphorilation in mitochondria from cabbage. Weed Sci. 16: 161-165.

M i s r a R., S i n g h J.S., S i n g h K. P., 1968. Dry matter production in sun and shade leaves and a simple method for measurement of primary productivity. Curr. Sci. 37: 306-307.

M o r e l a n d D. E., 1969. Inhibitors of chloroplast electron transport: Structural activity reaction. Progress in Photosynthetic Research, 3: 1693-1711.

$\mathrm{O} l \mathrm{e} \mathrm{ch} \mathrm{K.,} \mathrm{1966.} \mathrm{Influence} \mathrm{of} \mathrm{some} \mathrm{herbicides} \mathrm{on} \mathrm{photosynthesis} \mathrm{and} \mathrm{respiration} \mathrm{of} \mathrm{crops} \mathrm{and}$ weeds. 1. Atrazine. Annals Univ. Maria Curie-Skłodowska 21: 289-308.

Pu r c h i t M., M a 11 L. P., D u b e y P.S., 1976. Herbicidal pollution. Chlorophyll contents as an index of residual toxicity. Curr. Sci. 45.

R a o A. N., A r u n a A., D u b e y P. S., 1978. Chlorophyll content as an indicator of residual toxicity of triazine herbicides. Geobios. 5: 23-24.

Set lik I., B a rtos J., K u b l u I., 1960. Photosynthesis on leaf disc as a medium of photosynthetic capacity of crop plants. Biol. Plant, 2: 292-308.

S e t 1 i k I., S e s t a k Z., 1971. Use of leaf tissue samples in ventilated chambers for longterm measurements of photosynthesis. [In:] Plant Photosynthetic Production Manual of Method. Dr W. Junk N. V. Publ., The Haque, 316-342.

Sha d bold C. A., Wh it ing F. L., L y o n s J. M., 1964. Persistence of monuron and neburon under semiarid field conditions. Weeds, 12: 304.

W h e e 1 e r. H. L., H a $\mathrm{m}$ i $1 \mathrm{t}$ o $\mathrm{n}$ R. H., 1968. The leaf concentrarions of atrazine in cereal crops as related to tolerance. Weed Sci. 16: 7-10. 
Wpływ pozostałości w glebie niektórych herbicydów na zawartość chlorofilu i produktywność pierwotną roślin uprawianych w następnym roku oraz towarzyszących im chwastów

\section{Streszczen i e}

Badano wplyw pozostałości w glebie kilku herbicydów, jak: Atrataf (atrazyna), 2,4-D i Aresin (monolinuron) zastosowanych w poprzednim sezonie - na natężenie chlorofilu i na produktywność pierwotną Zea mays (kukurydza) i Cajanus cajan uprawianych w plodozmianie, jak również na towarzyszące im chwasty. Pozostałości wszystkich trzech herbicydów nie były toksyczne dla Zea mays, natomiast wykazywały toksyczne działanie na Cajanus cajan, pierwsza $z$ tych roślin wykazała na poletkach z pozostałościami wzrost pierwotnej produktywności i wzrost zawartości chlorofilu, podczas gdy druga wykazala spadek. Chwasty towarzyszące tym roślinom wykazaly wyraźne zmniejszenie zawartości chlorofilu oraz pierwotnej produktywności pod wpływem pozostałości herbicydów. Chwastem najbardziej podatnym na dzialanie pozostałości wszystkich trzech herbicydów byl Acalypha malabarica, podczas gdy Echinochloa colonum jest podatna na pozostałości atrazyny, lecz toleruje pozostałości dwóch innych herbicydów. W pracy przedstawiono zalecenia oparte na powyższych obserwacjach. 